\title{
Carbon contribution through bacterivory in larvae of the Pacific oyster Crassostrea gigas
}

\author{
Philippe A. Douillet* \\ Oregon State University, Department of Fisheries, Hatfield Marine Science Center, Newport, Oregon 97365, USA
}

\begin{abstract}
A bacterium (Strain CA2) that enhanced survival and growth of oyster Crassostrea gigas (Thunberg) larvae was used to determine the potential contribution of bacterial carbon towards the total carbon requirements of bivalve larvae. Experimental methods that reduced label recycling in ${ }^{14} \mathrm{C}$ feeding trials permitted determination of larval retention efficiencies for bacterial and algal (Isochrysis galbana) carbon when these foods were provided to larvae at equivalent carbon concentrations. Straight-hinged oyster larvae (ca $100 \mu \mathrm{m}$ mean shell length) fed CA2 bacteria at $1.5 \times 10^{7}{\text { cells } \mathrm{ml}^{-1}}^{-1}$ could meet $147 \%$ of their total metabolic carbon requirements with bacterial carbon retained in 'pulsechase ${ }^{14} \mathrm{C}$ feeding experiments. In addition, this bacterial carbon represented $48.5 \%$ of the carbon retained by straight-hinged larvae fed on a similar biomass of algal carbon ( $I$. galbana at 54000 cells $\mathrm{ml}^{-1}$ ). The potential contribution of bacterial carbon towards the metabolic carbon requirements of oyster larvae decreased as larvae grew in size. Only $41 \%$ of the total metabolic carbon requirements of a $283 \mu \mathrm{m}$ larva could be met by the bacterial carbon retained after feeding on CA2 bacteria at $1.5 \times 10^{7}$ cells $\mathrm{ml}^{-1}$.
\end{abstract}

KEY WORDS: Bacteria · Carbon · Oyster larvae

\section{INTRODUCTION}

Phytoplankton has long been successfully used for the culture of mollusc larvae (Cole 1937, Bruce et al. 1940, Davis 1950) and is still now generally accepted to be the principal food source of bivalve larvae (Webb \& Chu 1981, Bayne 1983). However, the metabolic requirements of bivalve larvae have been found to be higher than the algal concentrations determined in nature (Bayne 1983, Crisp et al. 1985, Melaouah 1989). Therefore, other food sources must supply nutrients for bivalves during their planktonic life stage.

Marine bacteria provide valuable food resources to protozoa and many species of invertebrates (Zobell \& Feltham 1938, Zhukova 1963, Haas \& Webb 1979 , Caron et al. 1982, Fenchel 1982, Rivkin et al. 1986, Sherr \& Sherr 1987). Although no bacterial strain

- Present address: The University of Texas at Austin, Marine Science Institute, PO Box 1267, Port Aransas, Texas 78373, USA added as sole food source has supported complete development of bivalve larvae (Davis 1950, 1953, Douillet 1991), additions of Strain CA2 to cultures of oyster larvae fed algae were found to enhance larval survival and growth compared with larval cultures fed algae alone (Douillet 1991, Douillet \& Langdon 1993). Axenic oyster larvae were able to ingest CA2 cells and assimilate carbon from either live or heat-killed bacteria (Douillet 1993). Thus, oyster larvae have the endogenous ability to utilize bacteria as a carbon source.

The objective of this study was to address 2 questions on the importance of the bacterial carbon contribution to bivalve larvae: (1) what is the potential contribution of bacterial carbon towards the total metabolic requirements of larvae during different stages of larval development, and (2) how does the bacterial carbon compares with the algal carbon contribution to straight-hinged bivalve larvae when both food items are provided under same conditions and carbon biomasses? 


\section{METHODS}

Carbon retention efficiencies for larvae of 2 different sizes when fed CA2 cells. Three independent experiments were carried out to compare the utilization of bacterial carbon by Crassostrea gigas (Thunberg) larvae of 2 size groups. Straight-hinged (ca $100 \mu \mathrm{m}$ shell length) and 10 to $12 \mathrm{~d}$ old larvae (200 to $300 \mu \mathrm{m}$ shell length) were obtained from the Whiskey Creek Hatchery in Netarts Bay, Oregon, USA. Twelve hours before each feeding experiment, larvae were placed at a density of 0.1 to $0.2 \mathrm{ind} . \mathrm{ml}^{-1}$ in $200 \mathrm{l} \mathrm{Nal}$ gene tanks containing sand-filtered seawater at $25^{\circ} \mathrm{C}$. Larvae were pre-fed by adding cells of Isochrysis galbana (clone ISO; Center for Culture of Marine Phytoplankton, Maine, USA) at 40000 cells $\mathrm{ml}^{-1}$ to the culture tanks. Algal concentrations did not drop below $50 \%$ of this concentration before the start of experiments. Larvae were washed with $0.2 \mu \mathrm{m}$ filtered and heat-sterilised seawater (FSSW) on a $64 \mu \mathrm{m}$ Nitex screen, placed in a separatory funnel filled with FSSW, and non-swimming larvae were allowed to settle out of suspension before being discarded. A sample of larvae was preserved in $2 \%(\mathrm{w} / \mathrm{v})$ buffered formaldehyde $(\mathrm{pH}=8)$ and copiously rinsed with FSSW on a Nitex screen. Formaldehyde-killed larvae were used as controls for passive uptake of label by larvae, either by direct adsorption of ${ }^{14} \mathrm{C}$ compounds, or by attachment of labelled bacteria to the external surface of the larvae.

To determine background ${ }^{14} \mathrm{C}$ activities, 4 subsamples of live and formalin-killed larvae were collected on $8 \mu \mathrm{m}$ (25 mm) Nuclepore filters, washed with $5 \mathrm{ml} 0.5 \mathrm{M}$ ammonium formate, dried by vacuum and transferred while held on the filters to Petri dishes where larvae were counted under a dissecting microscope. Moist Whatman GF/C filters $(25 \mathrm{~mm}$ ) were then carefully placed over the larvae held on the Nuclepore filters, to prevent loss of larvae during their transfer from the Petri dishes to $20 \mathrm{ml}$ scintillation vials. Protosol (New England Nuclear) tissue solubilizer $(0.5 \mathrm{ml})$ and distilled water $(0.2 \mathrm{ml})$ were added to the scintillation vials and the larvae digested at $50^{\circ} \mathrm{C}$ for $24 \mathrm{~h}$. After complete digestion of larval tissues, $4 \mathrm{ml}$ of Aquasol II and $2 \mathrm{ml}$ distilled water were added, the mixture gelled by vigorous agitation on a Vortex mixer and larval radioactivity measured using a Beckman LS 8000 or LS 6000 TA liquid scintillation counter (LSC). Quench correction was by the external standard ratio method. Larval ${ }^{14} \mathrm{C}$ activity was calculated by dividing measured ${ }^{14} \mathrm{C}$ activity by the number of larvae in each sample.

CA2 bacteria grown on marine agar 2216 (Difco) for 4 d were transferred to $1 / 10$ recommended concentration marine broth 2216 (Difco; $3.74 \mathrm{~g} \mathrm{l}^{-1}$ ) at a salinity of $30 \mathrm{ppt}$ and enriched with $0.5 \mathrm{~g}$ glucose $\mathrm{I}^{-1}$. Microbial cultures were incubated at $25^{\circ} \mathrm{C}$ and agitated on an orbital shaker. After $4 \mathrm{~d}$ of growth, the cells were washed twice in FSSW by repeated centrifugation and resuspension, and then added to $1 / 10$ marine broth 2216. All washes of bacteria by centrifugation were carried out at $20000 \times g$ for $10 \mathrm{~min}$, using FSSW at a salinity of 30 ppt. D-(U- $\left.{ }^{14} \mathrm{C}\right)$-glucose $(304.7 \mathrm{mCi}$ $\mathrm{mmol}^{-1}$; New England Nuclear, NEC-042X) in a 9:1 ethanol: water solution was added to the broth at a final concentration of $125 \mu \mathrm{Ci} \mathrm{l}^{-1}$. Bacteria were incubated in the labelling medium for $4 \mathrm{~d}$, harvested and washed twice with FSSW, and transferred to $1 / 10$ marine broth 2216 enriched with 0.5 g glucose ] $^{-1}$. Following a chase period of $4 \mathrm{~h}$, the cells were washed 3 times. After complete dispersion of cells in FSSW, a $4 \mathrm{ml}$ sample was taken, preserved in $1 \mathrm{ml} 10 \%(\mathrm{w} / \mathrm{v})$ formaldehyde and stored in the dark for up to $5 \mathrm{~d}$ at $5{ }^{\circ} \mathrm{C}$, for determination of cell numbers by the acridine orange staining technique (Hobbie et al. 1977). Four samples of $1 \mathrm{ml}$ were each filtered at low vacuum pressure $(<2 \mathrm{~cm} \mathrm{Hg})$ through $0.45 \mu \mathrm{m}$ Gelman Metricel GN-6 filters, washed with $5 \mathrm{ml} 0.5 \mathrm{M}$ ammonium formate and transferred to scintillation vials, which each received $4 \mathrm{ml}$ Aquasol II (New England Nuclear) and $2 \mathrm{ml}$ distilled water. Samples were gelled by vigorous agitation and radioactivity was determined by LSC. The specific ${ }^{14} \mathrm{C}$ activity of bacterial cells was determined by dividing the activity of particulate organic ${ }^{14} \mathrm{C}\left(\mathrm{PO}^{14} \mathrm{C}\right.$ ) in $1 \mathrm{ml}$ by the number of cells per $\mathrm{ml}$.

Larvae from the 2 size groups were washed with FSSW on $64 \mu \mathrm{m}$ Nitex screens and transferred at a density of 10 ind. $\mathrm{ml}^{-1}$ to screened chambers held in $1 \mathrm{l}$ beakers filled with $400 \mathrm{ml}$ FSSW. Each screened chamber consisted of a PVC tube $(3.85 \mathrm{~cm}$ radius) with a $64 \mu \mathrm{m}$ Nitex screen covering its base. Both treatments were duplicated. ${ }^{14} \mathrm{C}$-labelled CA2 cells were added to larval suspensions at a final concentration of $10^{7}$ cells $\mathrm{ml}^{-1}$. Rapid determinations of bacterial concentrations were necessary in larval feeding experiments and these determinations were performed spectrophotometrically (Douillet 1993). Water samples for determination of initial concentrations of bacteria were withdrawn after agitation of the larval cultures with plastic plungers. Samples were withdrawn using $10 \mathrm{ml}$ pipettes with $37 \mu \mathrm{m}$ Nitex screens covering their tips, to prevent removal of larvae. Samples were processed as described above and initial ${ }^{14} \mathrm{C}$ activity per bacterial cell calculated. The activity of ${ }^{14} \mathrm{C}$-labelled $\mathrm{CA} 2$ cells was determined immediately after addition of cells to larval suspensions and also at the end of the 10 min feeding period in order to detect any possible reduction in bacterial ${ }^{14} \mathrm{C}$ activity during the larval grazing period.

After exposing larvae to ${ }^{14} \mathrm{C}$-labelled cells for $10 \mathrm{~min}$, the screened chambers containing the larvae were removed from the bacterial suspensions, washed with FSSW and transferred to beakers to allow larvae to 
purge themselves on a diet of axenic ${ }^{60} \mathrm{Co}$-irradiated Isochrysis galbana (30000 cells ml ${ }^{-1}$; Douillet 1993). Immediately after resuspension of the larvae, a $20 \mathrm{ml}$ sample per chamber (ca 200 larvae) was taken for determination of accumulated radioactivity in larvae. Subsequently, the screened chambers containing larvae were removed from suspensions of irradiated algae every hour, washed with FSSW and transferred to fresh, axenic, irradiated algae suspensions. Frequent water changes reduced the risk of reingestion of ${ }^{14} \mathrm{C}$-labelled fecal material by larvae. Samples of larvae were taken from each chamber after transfer to fresh, irradiated algae suspensions. The volume of the irradiated algae suspension was reduced at each transfer in order to maintain constant larval densities over the purge period. After a purge period of $8 \mathrm{~h}$, larvae were next transferred to fresh, irradiated algae suspensions for $24 \mathrm{~h}$.

Passive adsorption of radioactivity by larvae $\left(\mathrm{dpm}_{\mathrm{ads}}\right.$. larva ${ }^{-1}$ ) was assessed simultaneously by exposing formalin-killed larvae at a density of 10 ind. $\mathrm{ml}^{-1}$ to ${ }^{14} \mathrm{C}$-labelled $\mathrm{CA} 2$ cells. The activity of ${ }^{14} \mathrm{C}$-labelled CA2 cells was determined immediately after addition of cells to larval suspensions and also at the end of the 10 min exposure to detect any possible reduction in bacterial ${ }^{14} \mathrm{C}$ activity. To estimate the contribution of dissolved organic ${ }^{14} \mathrm{C}\left(\mathrm{DO}^{14} \mathrm{C}\right)$ to larval uptake of radioactivity, live larvae were exposed to particle-free filtrates $(0.2 \mu \mathrm{m}$ Nuclepore filtered; $<2 \mathrm{~cm} \mathrm{Hg})$ of suspensions of ${ }^{14} \mathrm{C}$-labelled bacteria left for $2 \mathrm{~h}$ in FSSW. Unlabelled larvae were added at a density of 10 ind. $\mathrm{ml}^{-1}$ to the filtrates containing $\mathrm{DO}^{14} \mathrm{C}$ released by labelled bacteria. After $10 \mathrm{~min}$ exposure to either ${ }^{14} \mathrm{C}$ labelled $\mathrm{CA} 2$ cells or to $\mathrm{DO}^{14} \mathrm{C}$ released by labelled bacteria, the screens holding the larvae were removed from the beakers, the larvae were washed with FSSW and transferred to suspensions of irradiated algae. Larvae were immediately sampled for accumulated radioactivity and then transferred every hour to fresh suspensions of irradiated algae to determine the loss of accumulated radioactivity $\left[\left(\mathrm{dpm}_{\mathrm{ads}} \mathrm{larva}^{-1}\right)\right.$ and $\left(\mathrm{dpm}_{\mathrm{abs}}\right.$ larva $\left.\left.^{-1}\right)\right]$ over time at the same sampling intervals used for the determination of radioactivity in bacteria-fed larvae. Control treatments for absorption and adsorption of ${ }^{14} \mathrm{C}$ were duplicated.

Radioactivities accumulated by larvae were calculated by subtracting the mean larval background ${ }^{14} \mathrm{C}$ activity from the ${ }^{14} \mathrm{C}$ activities of larvae determined in each treatment. Labelled carbon remaining in larvae after feeding on radioactive food and during depuration (dpm larva ${ }^{-1}$ ) was determined by subtracting the sum of the mean activities of larvae in controls for passive uptake of label $\left(\mathrm{dpm}_{\mathrm{ads}}\right.$ larva $\left.^{-1}\right)$ and for active uptake of dissolved label $\left(\mathrm{dpm}_{\mathrm{abs}}\right.$. larva $\left.{ }^{-1}\right)$, from the ${ }^{14} \mathrm{C}$ activity remaining in bacteria-fed larvae at each sampling time. In this way, the rates of gut evacuation were determined.

Radioactivity determined in larvae after 10 min feeding on ${ }^{14} \mathrm{C}$-labelled bacteria $\left[\mathrm{dpm}\right.$ ingested larva ${ }^{-1}$ $(10 \mathrm{~min})^{-1}$ ] permitted estimation of ingestion rates because the feeding period was shorter than the larval gut passage time. Ingestion rates (IR) for larvae fed on CA2 cells were calculated on hourly bases as cells larva ${ }^{-1} h^{-1}$ as follows:

$$
\mathrm{IR}=\mathrm{dpm} \text { ingested larva }{ }^{-1} \mathrm{~h}^{-1} / \mathrm{dpm} \text { cell }^{-1}
$$

Clearance rates (CR) defined here as the volume of water swept clear of particles in unit time $\left(\mu l\right.$ larva $^{-1}$ $\mathrm{h}^{-1}$ ) were estimated by dividing ingestion rates (cells larva $^{-1} \mathrm{~h}^{-1}$ ) by the initial concentration of bacteria in larvae suspensions (cells $\mu \mathrm{I}^{-1}$ ).

Particles ingested by molluscan larvae are sorted in the stomach whereas non-digested particles are moved directly to the intestine, and particles to be digested are taken into the digestive diverticula for intracellular digestion (Bayne 1983). The rate of gut evacuation of bacteria-fed oyster larvae was characterized by a rapid decline in ${ }^{14} \mathrm{C}$ activity during the first $10 \mathrm{~min}$, followed by a more gradual decrease in activity during the next 3 to $6 \mathrm{~h}$, and finally by a linear decrease till the 24 th or 48 th hour of the purge period (Douillet 1993). Complete depuration of the larval digestive system including the digestive diverticula is essential for determination of carbon retention. Therefore, the most conservative approach to estimate retention efficiency was to select long depuration times resulting in underestimation of carbon assimilated because of ${ }^{14} \mathrm{CO}_{2}$ respiration and ${ }^{14} \mathrm{C}$ excretion (Douillet 1993). Retention efficiencies of bacterial ${ }^{14} \mathrm{C}$ (RE) were calculated as:

$\mathrm{RE}=\left(\mathrm{dpm}\right.$ retained larva ${ }^{-1} / \mathrm{dpm}$ ingested larva $\left.{ }^{-1}\right) \times 100$

where dpm ingested larva-1 corresponded to the radioactivity accumulated after the $10 \mathrm{~min}$ exposure to radioactive food, and dpm retained larva ${ }^{-1}$ was estimated as the radioactivity of larvae at the beginning of the linear decrease in activity observed during the depuration process.

Differences in initial cell concentrations, CR, IR and $R E$ between treatments with different larval sizes and between experiments were analyzed by 2-way ANOVA after arcsine-transforming retention efficiencies (Sokal \& Rohlf 1981). Where significant differences among treatments were indicated, Tukey's honestly significant difference test (T-HSD) was used to determine differences among individual treatments, at $\mathrm{p}=0.05$.

Carbon retention efficiencies for straight-hinged larvae fed on algae. A medium for labelling axenic 
Isochrysis galbana (clone ISO; Center for Culture of Marine Phytoplankton, Maine) with ${ }^{14} \mathrm{C}$ was prepared by aseptically acidifying $150 \mathrm{ml}$ of FSSW to $\mathrm{pH} 3$ with $1 \mathrm{~N}$ $\mathrm{HCl}$ to drive off $\mathrm{CO}_{2}$ and then restoring the $\mathrm{pH}$ to 8 by the addition of $1 \mathrm{~N} \mathrm{NaOH}$. Sterile nutrients (f/2 medium; Guillard \& Ryther 1962) and axenic I. galbana cells $\left(3.4 \times 10^{5}\right.$ cells $\mathrm{ml}^{-1}$, final concentration $)$ were added to the medium. $\mathrm{NaH}^{14} \mathrm{CO}_{3}$ $\left(50 \mathrm{mCi} \mathrm{mmol}^{-1}\right.$; New England Nuclear, NEC-086H) was added at a concentration of $1 \mu \mathrm{Ci} \mathrm{ml}^{-1}$. Algae were cultured at $20^{\circ} \mathrm{C}$ under cool-white fluorescent light, emitting 2500 to 3000 lux $24 \mathrm{~h} \mathrm{~d}^{-1}$. Exponentially growing ${ }^{14} \mathrm{C}$-labelled algal cells were washed 3 times with FSSW by repeated centrifugation (10 $\mathrm{min}$ at $3000 \times \mathrm{g}$ ) and resuspended in FSSW. The labelled algal stock suspension was filtered through an $8 \mu \mathrm{m}$ Nuclepore filter to remove clumped cells and algal concentrations were determined by counting 10 samples using a hemocytometer.

Straight-hinged larvae were fed ${ }^{14} \mathrm{C}$ labelled algae at a concentration of 54000 cells $\mathrm{ml}^{-1}$ for a period of $10 \mathrm{~min}$. The larvae were then purged by transfer to a suspension of 30000 cells ml-1 of ${ }^{60} \mathrm{Co}$-irradiated Isochrysis galbana. Sampling methods and control treatments for absorption and adsorption of ${ }^{14} \mathrm{C}$ were identical to those used in the previous experiments with larvae fed CA2 bacteria, except that 3 samples of larvae $(20 \mathrm{ml}$ each) were taken at each sampling time from each treatment flask. Average ${ }^{14} \mathrm{C}$ activities per larva for each treatment flask were calculated from triplicate samples. All treatments were duplicated. IR, CR and RE were calculated in the same way as described in experiments with CA2 cells.

Carbon content of Isochrysis galbana. Axenic I. galbana cells were cultured under identical conditions to those employed to culture algae for the algal feeding experiment, except that no $\mathrm{NaH}^{14} \mathrm{CO}_{3}$ was added to the cultures. Exponentially growing cells were harvested after reaching similar cell concentrations to those obtained for algal feeding experiments. Two replicate algal cultures were analyzed. Cell volumes were determined using a calibrated Coulter Channelyser 256, in conjunction with a Coulter

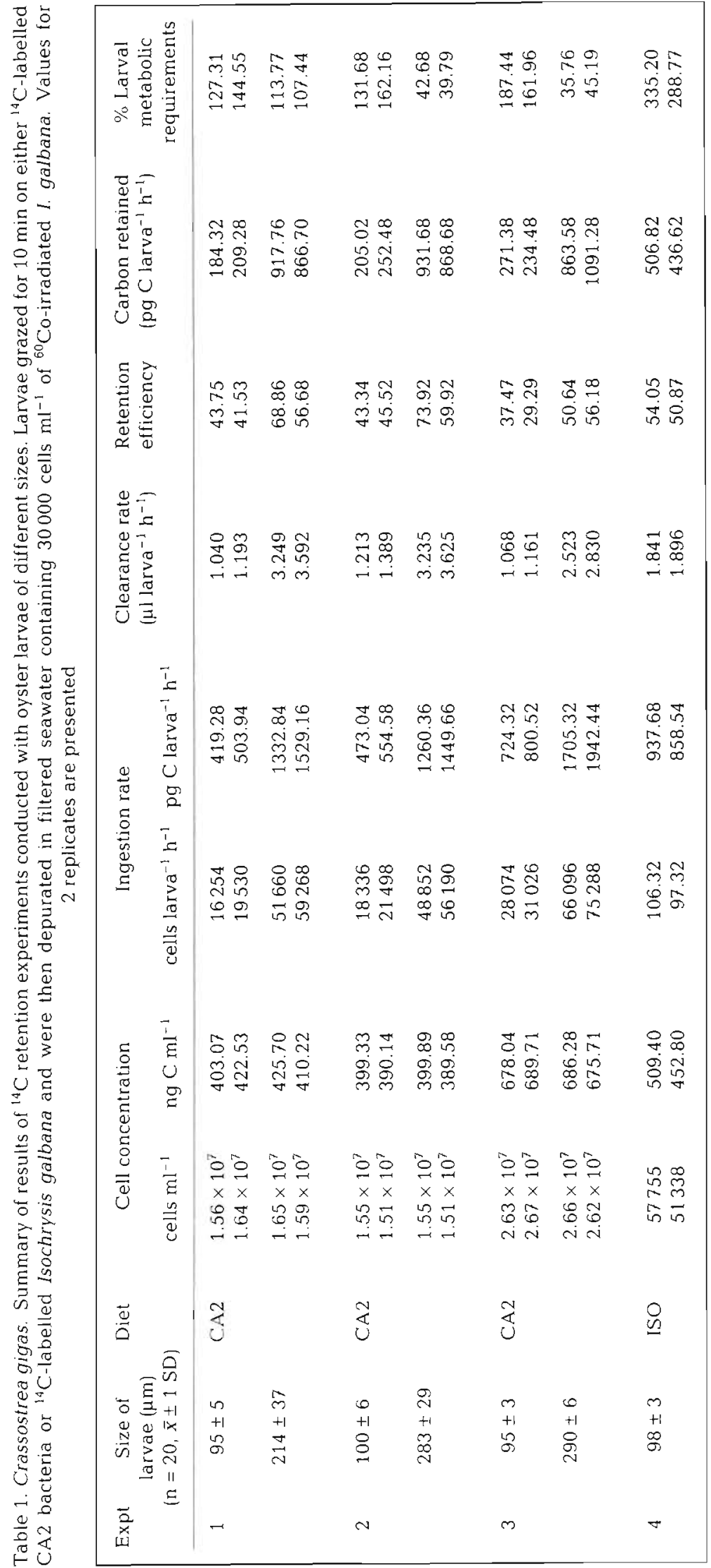


Counter (Model ZB1). Ten estimates of cell volume were carried out and an average cell volume was calculated. Carbon content of algal cells was determined by using the relationship between volume and carbon content, as determined by Strathmann (1967):

$$
\log C=0.866 \log V=0.46
$$

where $C=$ carbon $\operatorname{cell}^{-1}(\mathrm{pg})$ and $V=$ cell volume $\left(\mu \mathrm{m}^{3}\right)$.

Carbon retention in larvae fed CA2 cells or Isochrysis galbana. Assuming that CA2 and I. galbana cells were homogeneously labelled after culture for several days in ${ }^{14} \mathrm{C}$-labelled media, then the amount of carbon retained by each larva (C RET.) after feeding on labelled food followed by a complete purge of the digestive system with non-labelled food was estimated as:

$$
\text { C RET. }=(\mathrm{IR} \times \text { cell carbon content } \times \mathrm{RE}) / 100
$$

where $I R=$ ingestion rate expressed in terms of cells larva ${ }^{-1} \mathrm{~h}^{-1}$ and the carbon content of CA2 and I. galbana cells was expressed as pg C cell-1

Bacterial carbon retained by larvae of 2 different sizes (Expts 1, 2 \& 3), and the algal carbon retained by straight-hinged larvae (Expt 4) were calculated and presented in Table 1. Variation in larval carbon retention due to larval size and experiment (Expts 1, 2 \& 3) was analyzed by 2 -way ANOVA. Data for retained carbon were $\log$-transformed to reduce heterogeneity of variances (Cochran's test). Where significant differences among experiments were indicated, Tukey's HSD test was used to determine differences among individual experiments, at $\mathrm{p}=0.05$

Amounts of particulate organic carbon (POC) provided as CA2 cells in Expts 1,2\& 3 and as algal cells in Expt 4 were calculated by multiplying cell concentrations (cells $\mathrm{ml}^{-1}$ ) by carbon content per cell (pg C cell $^{-1}$ ). Carbon ingestion rates (CIR) for straighthinged larvae fed on these 2 diets were determined by multiplying cell ingestion rates (cells larva ${ }^{-1} \mathrm{~h}^{-1}$ ) by carbon content per cell ( $\left.\mathrm{pg} \mathrm{C} \mathrm{Cell}^{-1}\right)$. POC (pg C ml-1), CIR (pg $C$ larva $\left.{ }^{-1} \mathrm{~h}^{-1}\right), \mathrm{CR}\left(\mu \mathrm{l}\right.$ larva $\left.^{-1} \mathrm{~h}^{-1}\right)$, arcsinetransformed RE units and log-transformed CRET. were compared for algae and bacteria fed, straighthinged larvae in each of these 4 experiments by 1 -way ANOVA, after confirmation of homogeneity of variances (Cochran's test). Where significant differences were indicated, Tukey's HSD test was used, at $\mathrm{p}=0.05$, to determine differences among individual treatments.

Metabolic requirements of larvae. Respiration has conventionally been used to estimate metabolism. Gerdes (1983b) presented an allometric equation relating dry tissue weight to oxygen consumption of pre-fed larval Crassostrea gigas, determined at a salinity of 25 ppt and at $25^{\circ} \mathrm{C}$ :

$$
V_{\mathrm{O}_{2}}=0.00282 \mathrm{~W}^{0.96}
$$

where $V_{\mathrm{O}_{2}}=$ rate of oxygen consumption $\left(\mathrm{ml} \mathrm{O} \mathrm{O}_{2} \mathrm{~h}^{-1}\right.$ larva ${ }^{-1}$ ) and $W=$ dry tissue weight larva ${ }^{-1}$ ( $\mathrm{mg}$ ).

Dry tissue weight was determined for straighthinged larvae obtained from 2 different spawnings. Larvae were washed with $0.5 \mathrm{M}$ ammonium formate, collected by vacuum onto prewashed, preweighed (Perkin Elmer AD-2Z) $8 \mu \mathrm{m}$ Nuclepore filters (25 mm) and counted under a dissecting scope. Filters were folded to avoid loss of larvae, placed on small, preweighed aluminum foil trays and dried at $60^{\circ} \mathrm{C}$ to constant weight. Three samples from each spawning containing approximately 900 larvae each were processed and the weight per larva estimated by dividing the weight of larvae by the number of larvae on each filter. Dry tissue weight was estimated based on reports that $75 \%$ of larval dry weight corresponds to shell weight (Walne 1965, Millar \& Scott 1967). Dry tissue weights of oyster larvae of different sizes were also obtained using an equation based on data of Gerdes (1983a, b) relating larval shell length to dry tissue weight.

Estimates of metabolic energy requirements and equivalent weights of organic carbon respired by different sized larvae were calculated using the equation of Parsons \& Takahashi (1973):

mg C utilized $\mathrm{h}^{-1}=\mathrm{mlO}_{2}$ consumed $\mathrm{h}^{-1} \times 12 \times 2.4^{-1} \times R Q$

A respiratory quotient $(R Q)$ of 0.8 (Brody 1945) was used for all calculations.

The amount of carbon retained by larvae can be compared to estimates of larval metabolic requirements for carbon ( $\mathrm{C}$ met. req.) in order to determine if the diet could potentially provide enough carbon to meet larval requirements. Percent carbon metabolic requirements of larvae potentially supplied by diets were calculated as:

$$
\% \text { C met. req. }=(\mathrm{C} \text { RET. } / \mathrm{C} \text { met. req. }) \times 100
$$

where CRET. and C met. req, are both in pg $\mathrm{C}$ larva $^{-1} \mathrm{~h}^{-1}$

\section{RESULTS}

\section{Carbon retention efficiencies for larvae of 2 sizes when fed CA2 cells}

Decreases in the ${ }^{14} \mathrm{C}$ activities of bacterial cells during 10 min grazing periods were negligible $(<2.4 \%)$ in all 3 experiments. Nevertheless, average cell activities were calculated for each experiment, based on the assumption of a linear decrease in ${ }^{14} \mathrm{C}$ activity from ini- 


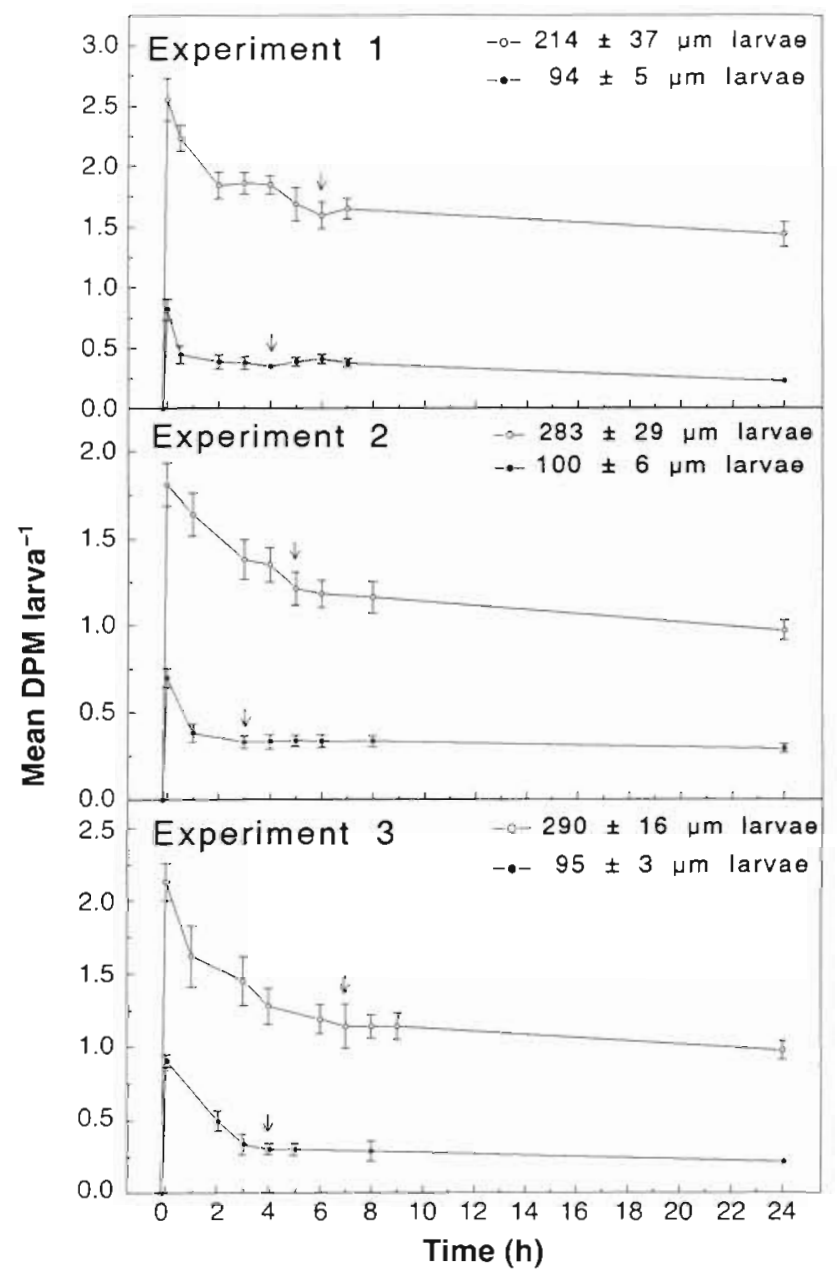

Fig. 1. Crassostrea gigas. Rates of ingestion and gut evacuation for large (mean shell length 214 to $290 \mu \mathrm{m}$ ) and small (mean shell length 94 to $100 \mu \mathrm{m}$ ) oyster larvae fed for $10 \mathrm{~min}$ on ${ }^{14} \mathrm{C}$-labelled CA2 bacteria and then depurated in filtered seawater containing 30000 cells $\mathrm{ml}^{-1}$ of ${ }^{60} \mathrm{Co}$-irradiated Isochrysis galbana. Symbols represent the means of 2 replicates and are shown with the range of values obtained. Arrows indicate points after which larvae were considered purged of ingested ${ }^{14} \mathrm{C}$

tial to final cell activities over the 10 min grazing period. Accordingly, CA2 cell activities in Expts 1, 2 \& 3 were estimated to be $2.77 \times 10^{-4} \pm 7.78 \times 10^{-6}(\bar{x} \pm$ $1 \mathrm{SD} ; \mathrm{n}=8), 2.08 \times 10^{-4} \pm 6.36 \times 10^{-6}$, and $1.81 \times 10^{-4} \pm$ $5.66 \times 10^{-6} \mathrm{dpm}$ cell $^{-1}$ respectively. Active uptake of label in dissolved form $\left(\mathrm{dpm}_{\text {it th. }}\right.$. larva $\left.{ }^{-1}\right)$ represented 5.73 to $7.87 \%$ and 8.73 to $11.67 \%$ of net accumulated activity in large and small larvae respectively. Passive adsorption of label by formalin-killed larvae accounted for 4.14 to $5.26 \%$ and 3.87 to $4.72 \%$ of net accumulated activity in large and small larvae respectively.

Results from the 3 comparative feeding experiments are presented in Fig. 1 and Table 1. Significant differences occurred among experiments in bacterial densi-
Table 2. Crassostrea gigas. Metabolic carbon requirements of various-sized oyster larvae

\begin{tabular}{|lccc|}
\hline Size of larva $(\mu \mathrm{m})$ & 94 & 214 & 290 \\
$\begin{array}{l}\text { Weight of larva }(\mathrm{ng}) \\
\begin{array}{l}\text { Oxygen consumption } \\
(\mathrm{pl} \mathrm{O} \text { larva }\end{array}\end{array}$ & 81.02 & 492.01 & 1542.1 \\
$\begin{array}{l}\text { Metabolic carbon } \\
\text { requirements } \\
(\mathrm{pg} \mathrm{C} \mathrm{larva}\end{array}$ & 142.68 & 1884 & 5634 \\
\hline
\end{tabular}

ties $(p<0.01)$, ingestion $(p<0.01)$ and clearance rates $(p=0.028)$. Bacterial densities were significantly different in all 3 experiments (T-HSD, $\mathrm{p}<0.05$ ). No significant differences were found among values for cell ingestion rates in Expts $1 \& 2$, while overall significantly higher cell ingestion rates occurred in Expt 3 than in Expts 1 \& 2 (T-HSD, p < 0.05). Larval clearance rates were found to differ between Expts $2 \& 3$, but neither were found to differ from clearance rates obtained in Expt 1 ( $T$-HSD, $p<0.05$ ). No differences among experiments were detected for retention efficiencies (2-way ANOVA, $p=0.07$ ). Cell densities were not significantly different between flasks holding large and small larvae in each experiment (2-way ANOVA, $p=0.89$ ), but cell ingestion and clearance rates were significantly higher for large compared with small larvae in all 3 experiments (2-way ANOVA, $\mathrm{p}<0.01$ ). Large larvae required a longer period of time to clear their guts of ${ }^{14} \mathrm{C}$-labelled material, compared with straight-hinged larvae (Fig. 1). Overall, large-sized larvae showed significantly higher carbon retention efficiencies than small-sized larvae (2-way ANOVA, $\mathrm{p}<0.01$ )

\section{Carbon retention efficiencies for straight-hinged larvae fed on algae}

Algal ${ }^{14} \mathrm{C}$ activity did not decrease significantly $(<3 \%)$ during the 10 min feeding period. The average cell activity during the $10 \mathrm{~min}$ feeding period was $0.29 \pm 0.009(\bar{x} \pm 1 \mathrm{SD} ; \mathrm{n}=4) \mathrm{dpm}_{\text {cell }}{ }^{-1}$. Active uptake of dissolved ${ }^{14} \mathrm{C}$ from labelled algal leachates $\left(\mathrm{dpm}_{\mathrm{abs}}\right.$ larva ${ }^{-1}$ ) and passive uptake from labelled algal suspensions $\left(\mathrm{dpm}_{a d s}\right.$ larva $\left.^{-1}\right)$ accounted respectively for 11.56 to $11.84 \%$ and 2.83 to $3.76 \%$ of net accumulated activity in larvae fed algae.

Clearance rate, ingestion rate and carbon retention efficiency for straight-hinged oyster larvae fed Isochrysis galbana are presented in Table 1. Patterns of gut depuration were similar for larvae fed on either algae or bacteria. Rapid larval loss of ${ }^{24} \mathrm{C}$ was detected dur- 


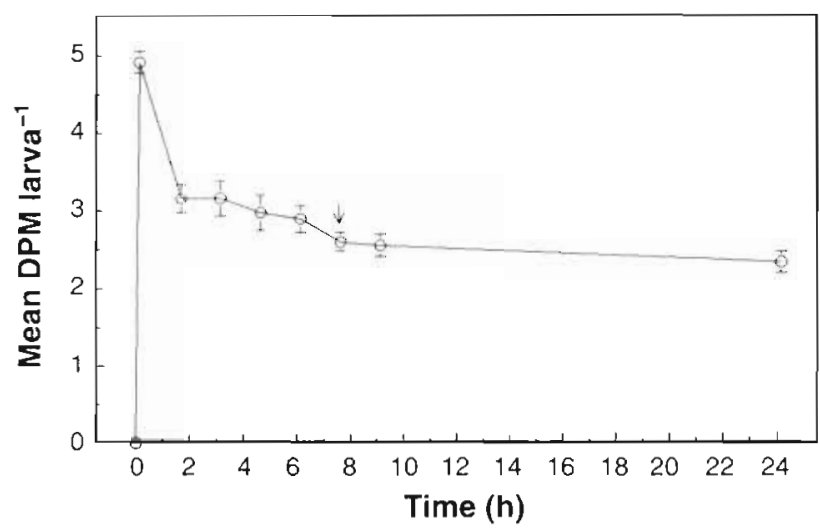

Fig. 2. Crassostrea gigas. Rates of ingestion and gut evacuation for straight-hinged oyster larvae fed for $10 \mathrm{~min}$ on ${ }^{14} \mathrm{C}$ labelled Isochrysis galbana and then depurated in filtered seawater containing 30000 cells $\mathrm{ml}^{-1}$ of ${ }^{60} \mathrm{Co}$-irradiated $I$. galbana. Symbols represent the means of 2 replicates and are shown with the range of values obtained. Arrows indicate points after which larvae were considered purged of ingested ${ }^{14} \mathrm{C}$

ing the first $1.5 \mathrm{~h}$ of depuration (Fig. 2 ). ${ }^{14} \mathrm{C}$ activity of larvae decreased at a more gradual rate over the following $6 \mathrm{~h}$. After $7.5 \mathrm{~h}$ depuration, the decrease in larval activity followed a constant slope, indicating that the gut was purged of labelled organic matter.

\section{Carbon content of CA2 and Isochrysis galbana cells}

In order to compare utilization of bacteria and algae by oyster larvae, computations were carried out based on the carbon content of each food type. The average carbon content per CA2 cell was estimated at $25.8+2.6$ $\mathrm{fg} \mathrm{cell}^{-1}$ (Douillet 1993). The volume of cells of Isochrysis galbana was determined to be $41.99 \pm 2.22 \mu \mathrm{m}^{3}$ ( $\bar{x} \pm$ $1 \mathrm{SD} ; \mathrm{n}=10$ ). The carbon content of an algal cell with this volume was calculated, using Strathmann's (1967) equation, as $8.82 \mathrm{pg} \mathrm{cell}^{-1}$.

\section{Carbon retention in larvae fed bacteria or algae}

No differences among Expts 1, 2 \& 3 were detected for the amounts of carbon retained by large and small larvae (2-way ANOVA, $p=0.18$ ). Overall, large-sized larvae retained significantly greater amounts of carbon than small-sized larvae ( 2 -way ANOVA, $p<0.01$ ). Retention efficiencies decreased, although not significantly, in Expt 3 where ingestion rates were highest. The resulting effect was that larvae retained similar amounts of carbon during each experiment despite variation in bacterial concentrations from 1.5 to $2.6 \times$ $10^{7}$ cells $\mathrm{ml}^{-1}$. Further experiments are required to determine if larvae regulate carbon retention rates when exposed to a wide range of bacterial concentrations.

The amount of POC added to cultures in the form of CA2 cells in Expts 1, 2 and algal cells in Expt 4 did not differ significantly among experiments, while a significantly higher amount of POC was provided in Expt 3 (T-HSD, $\mathrm{p}<0.05$ ). No significant differences in carbon ingestion rates were detected between Expts 1 \& 2 and between Expts $3 \& 4$ (T-HSD, p < 0.05). Carbon ingestion rates were higher in Expts 3 \& 4 than in Expts 1 \& 2 (T-HSD, $p<0.05$ ). Clearance rates and amounts of carbon retained by larvae did not differ among experiments with CA2 bacteria (Expts 1, 2 \& 3), while both parameters were significantly higher (T-HSD, $p<0.05$ ) for larvae fed on algae (Expt 4). Larval retention efficiencies for ingested carbon were not significantly different among Expts 1, 2 \& 4 and among Expts 1, 2 \& 3 , but a significant difference was found between Expts 3 \& 4 (T-HSD, $\mathrm{p}<0.05)$.

\section{Metabolic requirements of larvae}

The dry tissue weight of straight-hinged larvae was determined to be $84.93 \pm 19.39 \mathrm{ng} \mathrm{larva}^{-1}(\bar{x} \pm 1 \mathrm{SD}$; $n=6$ ). Because of close agreement between this value and the dry tissue weight calculated for straighthinged larvae using the formula derived from Gerdes (1983b), it was considered satisfactory to employ Gerdes' method to determine weights of various-sized larvae which, in turn, would allow estimation of larval metabolic requirements. Examples of oxygen consumption by various-sized larvae and the equivalent amounts of carbon utilization per larva are given in Table 2.

Different-sized larvae were exposed to similar bacterial concentrations in each one of 3 experiments (Expts 1, 2 \& 3); however, in all cases, large larvae (214 to $290 \mu \mathrm{m}$ shell length) showed significantly higher clearance rates, ingestion rates, retention efficiencies and, consequently, retained larger amounts of carbon than small larvae (94 to $100 \mu \mathrm{m}$ shell length). Because of the dramatic increase in metabolic requirements as larvae grow in size (Table 2), the potential contribution of retained bacterial carbon to the metabolic requirements of larvae is more significant for small, than for large, larvae.

When Isochrysis galbana and CA2 cells were added to larval cultures at similar POC concentrations, highest ingestion rates, clearance rates and amounts of carbon retained were evident in larvae fed algae. However, carbon retention efficiencies were not significantly different for larvae fed on either food type. In contrast, when higher concentrations of bacterial POC 
than algal POC were added to larval cultures, then similar carbon ingestion rates were evident in larvae fed on either food type, but clearance rates, amounts of carbon retained and carbon retention efficiencies were significantly higher for larvae fed algae than for larvae fed bacteria. Consequently, under all conditions tested, larvae retained larger amounts of carbon from algae than from bacteria.

\section{DISCUSSION}

In order to evaluate the contribution of bacterial carbon to bivalve larvae, care should be taken to avoid experimental artifacts that may result in overestimation of ingestion of bacteria and assimilation of bacterial carbon. The methods used in this research were conservative as discussed in Douillet (1993) (e.g. a short feeding period on labelled food and an inert purge substrate reduced the possibility of label recycling, long depuration times guaranteed that only assimilated label would be considered retained carbon and frequent water changes prevented reingestion of label released in feces). The same methods were used when feeding bivalves with either bacteria or algae. Therefore, the validity of the methods can be evaluated by comparing the results in algae feeding experiments with values reported in the literature.

Clearance rates for straight-hinged larvae fed Isochrysis galbana at $5 \times 10^{4}$ cells $\mathrm{ml}^{-1}$ equalled $1.869 \mu \mathrm{l}$ larva ${ }^{-1} \mathrm{~h}^{-1}$. A clearance rate of $1.2 \mu l$ larva $^{-1} \mathrm{~h}^{-1}$ was estimated by Gallager et al. (1989) for $4 \mathrm{~d}$ old scallop larvae fed $I$. galbana at $5 \times 10^{4}$ cells $\mathrm{ml}^{-1}$. Gerdes (1983a) reported clearance rates varying from 0.92 to $3.62 \mu 1$ larva $^{-1} \mathrm{~h}^{-1}$ for 95 to $105 \mu \mathrm{m}$ sized larval Crassostrea gigas fed $1 \times 10^{5} \mathrm{I}$. galbana cells $\mathrm{ml}^{-1}$, while larvae 91 to $99 \mu \mathrm{m}$ in size had clearance rates ranging from 1.9 to $12.3 \mu \mathrm{l}$ larva $^{-1} \mathrm{~h}^{-1}$ when fed $I$. galbana at $2.5 \times 10^{4}$ cells mil ${ }^{-1}$. Therefore, the clearance rate estimated in this study with $I$ galbana is within the reported range for bivalve larvae. The clearance rate of prodissoconch II Crassostrea virginica larvae (ca $179 \mu \mathrm{m}$ mean shell length) for 0.2 to $0.8 \mu \mathrm{m}$ sized particles was determined as $1.6 \mu$ larva $^{-1} \mathrm{~h}^{-1}$ (Baldwin \& Newell 1991). In this study, the clearance rates for CA2 bacteria were 1.15 to $1.3 \mu \mathrm{l}$ larva $^{-1} \mathrm{~h}^{-1}$ for 94 to $100 \mu \mathrm{m}$ larvae, and 2.67 to $3.43 \mu \mathrm{l}$ larva $^{-1} \mathrm{~h}^{-1}$ for 214 to $290 \mu \mathrm{m}$ larvae.

Average ingestion rate of Isochrysis galbana by straight-hinged larval Crassostrea gigas equalled 101.8 cells larva ${ }^{-1} \mathrm{~h}^{-1}$. Most estimates of algal ingestion rates have been carried out with large-sized bivalve larvae (e.g. Bayne 1965. Walne 1965). Ingestion rates have been related to shell length of larval Mytilus edulis according to equations developed by Sprung (in Bayne
1983) and Jespersen \& Olsen (1982), which predict respectively ingestion rates of 90.6 and 319.2 cells larva ${ }^{-1} \mathrm{~h}^{-1}$ for mussel larvae $98 \mu \mathrm{m}$ in shell length $(80 \mathrm{ng}$ dry tissue weight) when fed on algae at 54000 cells $\mathrm{ml}^{-1}$. An ingestion rate of 61.8 cells larva ${ }^{-1} \mathrm{~h}^{-1}$ was calculated for $4 \mathrm{~d}$ old scallop larvae fed on I. galbana based on data of Gallager et al. (1989). Similarly, ingestion rates calculated from data of Gerdes (1983a) for larval C. gigas ( 76 to $106 \mu \mathrm{m}$ shell length) ranged between 46.2 and 312 cells larva ${ }^{-1} \mathrm{~h}^{-1}$. Grazing rates of Crassostrea virginica larvae on natural assemblages of phytoplankton were inversely proportional to both larval density and experimental duration (Fritz et al. 1984). In this study, both of these factors were kept constant between experimental runs and food types. Experimental factors that could have affected measurements of ingestion rates in this study include the gut fullness of larvae at the beginning of the labelling period. Larvae were pre-fed algae at optimal concentrations for $24 \mathrm{~h}$, but were starved for $20 \mathrm{~min}$ while being manipulated at the beginning of each experiment. The feeding rate in short-term experiments is partly dependent on the nutritional adaptation of the organism (McMahon \& Rigler 1965). Feeding rates of bivalve larvae have been found to be 25 times higher in larvae with empty guts than in larvae with full guts (Gallager 1988). However, algal ingestion rates determined in this study were not higher than published values, suggesting that the methods used in this study did not result in enhanced grazing activity.

A wide range of biovolume estimates for cells of Isochrysis galbana has been reported, extending from $23 \mu \mathrm{m}^{3}$ (Crisp et al. 1985) to $80 \mu \mathrm{m}^{3}$ (Omori \& Ikeda 1984, Fabregas et al. 1986). An intermediary biovolume of 41.99 was determined for I. galbana in this study. Not surprisingly, the calculated carbon content per cell (8.82 pg C cell ${ }^{-1}$ ) represents an intermediate value for published estimates, which range from $5.1 \mathrm{pg}$ $\mathrm{C}$ cell ${ }^{-1}$ (Omori \& Ikeda 1984) to $20 \mathrm{pg} \mathrm{C}$ cell ${ }^{-1}$ (Falkowski et al. 1985).

Assimilation efficiencies have been found to be affected by factors such as temperature, animal size, food concentration and diet (Lampert 1977, Lampert \& Egg 1977). Assimilation efficiencies of mussel larvae have been reported to decrease from 45 to $31 \%$ as algal concentrations increase (Jespersen \& Olsen 1982). Similarly, a decrease in assimilation efficiencies from 80 to $30 \%$ as a result of higher algal concentrations was reported by Crisp et al. (1985). Assimilation efficiencies of $71 \%$ were reported for larval Mytilus edulis (Bayne 1976), 12.5 to 40\% (Walne 1965) and 40 to $77 \%$ (Gabbott \& Holland 1973) for Ostrea edulis, and 39 to $60 \%$ for scallop Argopecten irradians larvae (Gallager et al. 1989). A carbon retention efficiency of $52 \%$ determined in this study with I. galbana corre- 
sponds to the upper reported estimates of assimilation efficiencies for bivalve larvae. The amount of algal carbon retained by straight-hinged larvae $(98 \mu \mathrm{m}$ shell length) was equivalent to more than 3 times the estimated larval metabolic requirements

Straight-hinged oyster larvae (mean shell length $100 \mu \mathrm{m}$, Expt 2) fed CA2 bacteria at $1.5 \times 10^{7} \mathrm{cells} \mathrm{ml}^{-1}$ could meet $147 \%$ of their carbon metabolic requirements with the bacterial carbon retained after complete purge of their digestive systems. This bacterial carbon represented $48.5 \%$ of the carbon retained by larvae fed on a similar concentration of carbon in the form of algae. The bacterial carbon contribution towards larval metabolic requirements decreased as larvae increased in size. Only $41 \%$ of the total metabolic carbon requirements of a $283 \mu \mathrm{m}$ larva could be met by the bacterial carbon retained after feeding on Strain CA2 at $1.5 \times 10^{7}$ cells $\mathrm{ml}^{-1}$.

Carbon assimilation rate does not necessarily reflect the nutritional value of the assimilated diet (Lampert 1977); for example similar assimilation efficiencies were determined for Daphnia pulex fed either bluegreen algae which did not provide sufficient nutrition to support growth of this crustacean, or green algae that supplied all nutritional requirements of $D$. pulex (Arnold 1971, Lampert 1977). Bacteria alone were found to be an inadequate diet for oyster larvae (Davis 1950, 1953, Douillet 1991), probably due to the lack of long-chain polyunsaturated fatty acids (Kates 1964, Perry et al. 1979) and sterols (Lehninger 1975), both apparently required by bivalves (Trider \& Castell 1980 , Langdon \& Waldock 1981). However, bacteria may be a valuable food item because of its high nitrogen content, as demonstrated by the low atomic $\mathrm{C} / \mathrm{N}$ ratio (4.01) of CA2 bacteria (Douillet 1993). Furthermore, valuable nutrients for bivalve larvae such as vitamins (Kutsky 1981) are produced by bacteria. Bacterial supply of essential nutrients was proposed as a mechanism by which additions of CA2 bacteria significantly enhanced the growth of larvae fed algal diets (Douillet 1991, Douillet \& Langdon 1993).

Preferential ingestion of bacteria over phytoplankton has been demonstrated in asteroid larvae in the Antarctic (Rivkin et al. 1986) whereas phytoplankton is the principal food source for some temperate echinoderm species (Strathmann 1971). Some crustaceans have been found to switch between various food sources over time, adapting to whatever food resource becomes available or abundant (Lee et al. 1976). Food selection may be an adaptation to differences in the natural availability of food (Rivkin et al. 1986), or to reduce interspecific competition (Hicks \& Coull 1983). Provasoli et al. (1959) suggested that supplemental feeding (i.e. feeding on more than one food source) was a trophic strategy used by consumers in nature; for example, some copepods have been found to use detritus to supply the majority of their energy needs while requiring algae for egg production (Heinle et al. 1977). Ingestion and retention of bacterial carbon was demonstrated in different-sized oyster larvae, therefore, bacteria can be used as a food source throughout all larval development. However, the bacterial contribution to larval carbon metabolic requirements may be more significant for small than for large larvae.

The energy requirements for survival and growth of bivalve larvae have been reported to be greater than that which could be met by algae alone, at algal concentrations commonly reported in coastal waters (Walne 1956, Crisp et al. 1985, Melaouah 1989). Up to $90 \%$ of the biomass (measured as chlorophyll a) of marine phytoplankton has been attributable to picoplankton (size range 0.2 to $2.0 \mu \mathrm{m}$ ) (Li et al. 1983); however, their contribution to the nutrition of bivalve larvae is not clear. Mercenaria mercenaria larvae were able to ingest and digest the cyanobacterium Synechococcus sp. (S. M. Gallager, J. B. Waterbury \& D. K. Stoecker unpubl.). This diet did not support growth of larvae when provided alone, but growth of larvae fed algae of good nutritional quality was enhanced when Synechococcus sp. was added as a dietary supplement. Larvae of the scallop Argopecten irradians efficiently digested cells of Aureococcus anophagefferens (Gallager et al. 1989). However, the contribution of this picoplankton species to the nutrition of bivalve larvae may be very limited due to inefficient cell capture by larvae, poor growth of larvae fed only on this diet, adverse effects on larval growth when fed in combination with Isochrysis aff. galbana clone TISO, and deleterious effects on survival and growth when fed to larvae at near-bloom concentrations (Gallager et al. 1989).

Crisp et al. (1985) suggested that non-algal food sources make a significant contribution to bivalve larvae nutrition in the marine habitat. Imai \& Hatanaka (1949) cultured larval Crassostrea gigas on a diet of a naked heterotrophic flagellate (Monas sp.). However, several authors were unable to culture bivalve larvae with either the same flagellate used by Imai or the naked flagellate Bodo sp. (Walne 1956, Loosanoff \& Davis 1963). Ingestion of flagellates and ciliates by $C$. virginica larvae was demonstrated using radiotracer experiments (Baldwin \& Newell 1991). Straight-hinged oyster larvae have a mouth opening of less than $10 \mu \mathrm{m}$ (Bruce et al. 1940, Ukeles 1969); therefore this should limit the size of protozooplankton that could be ingested by small larvae. Larger-sized larvae (ca $179 \mu \mathrm{m}$ mean shell length) can ingest particles up to $30 \mu \mathrm{m}$ in size (Baldwin \& Newell 1991), and therefore may be better suited to feed on large protozooplankton. Heterotrophic nanoplankton concentrations in coastal and open ocean environments range from $10^{2}$ to 
$10^{3}$ cells $\mathrm{ml}^{-1}$, increasing to $10^{4}$ cells $\mathrm{ml}^{-1}$ in eutrophic waters (Fenchel 1982, Caron 1983, Sherr \& Sherr 1984). These concentrations are not different from those of phytoplankton determined in the same environments (Caron 1983)

Direct utilization of dissolved organic matter as a food source of invertebrates was advanced early this century by Pütter (1909), and other researchers examined the role of different dissolved compounds in the nutrition of bivalve larvae (see review by Ukeles 1969 , Manahan 1990). Manahan (1989) demonstrated that axenic Crassostrea gigas larvae can take up dissolved amino acids from seawater. Larvae exposed to high amino acid concentrations $(10 \mu \mathrm{M})$ could potentially meet $100 \%$ of their energy requirements for oxidative metabolism by amino acid uptake. As recognized by Manahan (1989), these concentrations are unrealistically high for the marine environment (amino acid concentrations in marine habitats $c a<0.1 \mu \mathrm{M}_{\text {i }}$ Heinrichs \& Williams 1985, Williams 1986) and may only be found in 'microzones' of high nutrient concentration (Nissen et al. 1984). The ability of larvae to take advantage of these microzones of high nutrient concentration has yet to be demonstrated.

Utilization of detritus prepared from plant and animal material was demonstrated to occur in adult oysters (Gavard 1927) and larvae (DeBoer 1975); however, the chemical composition of these organic aggregates may have differed significantly from that of natural detritus. Larvae of different species of bivalves appear to have different nutritional requirements, as indicated by the findings of Loosanoff (1954) on the ability of larvae of the clam Mercenaria mercenaria to utilize a greater variety of natural foods than larvae of the oyster Crassostrea virginica. Larvae of $M$. mercenaria grew when fed on a diet of dead Isochrysis galbana (Hidu \& Ukeles 1962, Chanley \& Normandin 1967), whereas larval $C$. virginica did not grow when fed on this non-living diet (Hidu \& Ukeles 1962). Other studies have shown that organic detritus from different sources was not utilized by different species of bivalve larvae (Davis 1950, 1953, Loosanoff et al. 1951, Loosanoff 1954, Loosanoff \& Davis 1963).

Bacteria are ubiquitous in the marine environment, and concentrations up to $10^{7}$ cells $\mathrm{ml}^{-1}$ have been reported in environments where bivalve larvae are likely to be found (Douillet 1993). Vertical heterogeneity in bacterial abundance, with concentrations varying by up to 3.5 -fold over distances of $10 \mathrm{~cm}$, was reported in coastal waters by Mitchell \& Fuhrman (1989). Further research is required to determine concentrations of bacteria that bivalve larvae may encounter while swimming through the water column.

In summary, bacterivory was shown to be important in the nutrition of oyster larvae in this study, in which
CA2 bacteria were fed to larvae in experiments designed to reduce major sources of error (e.g. label recycling) in estimating utilization of bacteria as a food source. The contribution that bacteria may have to the carbon requirements of small (94 to $100 \mu \mathrm{m}$ shell length) oyster larvae was shown to exceed larval carbon metabolic requirements. Cell size and carbon content of CA2 bacteria were within reported ranges for bacteria found in natural environments (Douillet 1993); however, not all bacterial strains have similar effects on bivalve larvae (Douillet 1991, Douillet \& Langdon 1993), and extrapolation of results obtained with Strain CA2 to describe interactions between populations of bacteria and bivalve larvae in natural conditions should be undertaken with caution.

Acknowledgements. This research formed part of the author's doctoral thesis submitted to Oregon State University. Support for this research was provided by a Markham Award to this project and by the Oregon Sea Grant, NOAA, grant no. NA 85AA-D-SG095 to Dr Christopher J. Langdon. I am indebted to Dr Langdon for providing laboratory facilities and encouragement, to Drs R. Y. Morita, R. Griffiths and G. Taghon for helpful discussions, to L. Hanson (Whiskey Creek Hatchery, Netarts Bay, Oregon) for supplying oyster larvae and to my friends and colleagues at the Hatfield Marine Science Center for their support and collaboration.

\section{LITERATURE CITED}

Arnold, D. E. (1971). Ingestion, assimilation, survival, and reproduction by Daphnia pulex fed seven species of bluegreen algae. Limnol. Oceanogr, 16(6): 906-920

Baldwin, B. S., Newell, R. I. E. (1991). Omnivorous feeding by planktotrophic larvae of the eastern oyster Crassostrea virginica. Mar. Ecol. Prog. Ser. 78(3): 285-301

Bayne, B. L. (1965). Growth and the delay of metamorphosis of the larvae of Mytilus edulis (L). Ophelia 2: 1-47

Bayne, B. L. (1976). The biology of mussel larvae. In: Bayne, B. L. (ed.) Marine mussels, their ecology and physiology. Cambridge Univ. Press, London, p. 81-120

Bayne, B. L. (1983). Physiological ecology of marine molluscan larvae. In: Verdonk, N. H., van den Biggelaar, J. A. M. Tompa, A. (eds.) The Mollusca, Vol. III. Academic Press, New York, p. 299-343

Brody, S. (1945). Bioenergetics and growth. Reinhold Publishing Co., New York

Bruce, J. R., Knight, M., Parke, M. W. (1940). The rearing of oyster larvae on an algal diet. J. mar. biol. Ass. U.K. 24: $337-374$

Caron, D. A. (1983). Technique for enumeration of heterotrophic and phototrophic nanoplankton, using epifluorescence microscopy, and comparison with other procedures. Appl environ. Microbiol. 46: 491

Caron, D. A., Davis, P. G., Madin, L. P., Sieburth, J. McN (1982). Heterotrophic bacteria and bacterivorous protozoa in oceanic microaggregates. Science 218: 795-797

Chanley, P., Normandin, R. F. (1967). Use of artificial foods for larvae of the hard clam, Mercenaria mercenaria (L.). Proc. natl Shellfish. Ass. 57: 31-37

Cole, H. A. (1937). Experiments in the breeding of oysters 
(Ostrea edulis) in tanks, with special reference to the food of the larvae and spat. Fishery Invest., Lond. 15: 1-28

Crisp, D. J., Yule, A. B., White, K. N. (1985). Feeding by oyster larvae: the functional response, energy budget and a comparison with mussel larvae. J. mar. biol. Ass. U.K. 65 $759-783$

Davis, H. C. (1950). On food requirements of larvae of Ostrea virginica. Anat. Rec. 108: 132-133

Davis, H. C. (1953). On food and feeding of larvae of the American oyster, C. virginica. Biol. Bull. 104: 334-350

DeBoer, J. A. (1975). The utilization of non-living algal products by larval oysters. Ph.D. thesis, Oregon State University, Corvallis

Douillet, P. (1991). Beneficial effects of bacteria on the culture of larvae of the Pacific oyster Crassostrea gigas (Thunberg), Ph.D thesis, Oregon State University, Corvallis

Douillet, P. (1993). Bacterivory in Pacific oyster Crassostrea gigas larvae. Mar. Ecol. Prog. Ser. 98: 123-134

Douillet, P., Langdon, C. J. (1993). Effects of marine bacteria on the culture of axenic oyster Crassostrea gigas (Thunberg) larvae. Biol. Bull. 184: 36-51

Fabregas, J., Herrero, C., Cabezas, B., Abalde, J. (1986). Biomass production and biochemical composition in mass cultures of the marine microalga Isochrysis galbana Parke at varying nutrient concentrations. Aquaculture 53: $101-113$

Falkowski, P. G., Dubinsky, Z., Wyman, K. (1985). Growthirradiance relationships in phytoplankton. Limnol. Oceanogr. 30(2): 311-321

Fenchel, T (1982). Ecology of heterotrophic microflagellates. IV Quantitative occurrence and importance as bacterial consumers. Mar. Ecol. Prog. Ser. 9: 35-42

Fritz, L. W., Lutz, R. A., Foote, M. A., Van Dover, C. L., Ewart, J. W. (1984). Selective feeding and grazing rates of oyster (Crassostrea virginica) larvae on natural phytoplankton assemblages. Estuaries 7(4b): 513-518

Gabbott, P. A., Holland, D. L. (1973). Growth and metabolism of Ostrea edulis larvae. Nature 241(5390): 475-476

Gallager, S. M. (1988). Visual observations of particle manipulation during feeding in larvae of a bivalve mollusc. Bull. mar. Sci. 43(3): 344-365

Gallager, S. M., Bricelj, V. M., Stoecker, D. K. (1989). Effects of the brown tide alga on growth, feeding physiology and locomotory behavior of scallop larvae (Argopecten irradians). In: Cosper, N. Y. E., Bricelj, V. M., Carpenter, E. (eds.) Novel phytoplankton blooms, causes and impacts of recurrent brown tide and other unusual blooms. Coastal and estuarine studies. Springer-Verlag, New York, p. $511-541$

Gavard, D. (1927). De quoi se nourrissent les huîtres? Leur nourriture envisageé au point de vue 'Ostreiculture'. Bull. Trav. Stat. Aquic. Pêche Castiglione 2: 237-254

Gerdes, D. (1983a). The Pacific oyster Crassostrea gigas, Part I. Feeding behaviour of larvae and adults. Aquaculture 31 : $195-219$

Gerdes, D. (1983b). The Pacific oyster Crassostrea gigas, Part II. Oxygen consumption of larvae and adults. Aquaculture 31: $221-231$

Guillard, R. R. L., Ryther, J. H. (1962). Studies on marine planktonic diatoms. I. Cyclotela nana Hustedt and Detonula confervacea Cleve Can. J. Microbiol. 8: 229-239

Haas, L. W., Webb, K. L. (1979). Nutritional mode of several non-pigmented microflagellates from the York River Estuary, Virginia. J. exp. mar. Biol. Ecol. 39: 125-134

Heinle, D. R., Harris, R. P., Ustach, J. F., Flemer, D. A. (1977). Detritus as food for estuarine copepods. Mar. Biol. 40: $341-353$
Henrichs, S. M., Williams, P. M. (1985). Dissolved and particulate amino acids and carbohydrates in the sea surface microlayer Mar. Chem. 17: 141-164

Hicks, G. R. F., Coull, B. C. (1983). The ecology of marine meiobenthic harpacticoid copepods. Oceanogr. mar. Biol. A. Rev. $21.67-175$

Hidu, H. J., Ukeles, R. (1962). Dried unicellular algae as food for the larvae of the hard shell clam. Mercenaria mercenaria. Proc. natl Shellfish. Ass. 53: 85-101

Hobbie, J. E., Daley, R. J., Jasper, S. (1977). Use of Nuclepore filters for counting bacteria by fluorescence microscopy. Appl environ. Microbiol. 33: 1225

Imai, T., Hatanaka, M. (1949). On the artificial propagation of the Japanese common oyster, Ostrea gigas Thun., by noncolored naked flagellates. Bull. Inst. Agric. Res. Tohoku Univ. 1: $33-46$

Jespersen, H., Olsen, K. (1982). Bioenergetics in veliger larvae of Mytilus edulis L. Ophelia 21(1): 101-113

Kates, M. (1964). Bacterial lipids. Adv. Lipid Res. 2: 17-90

Kutsky, R. J. (1981). Handbook of vitamins, minerals, and hormones. Van Nostrand Reinhold, New York

Lampert, W. (1977). Studies on the carbon balance of Daphnia pulex as related to environmental conditions. I. Methodological problems of the use of ${ }^{14} \mathrm{C}$ for the measurement of carbon assimilation. Arch. Hydrobiol. Suppl. 48(3/4): $287-309$

Lampert, W., Egg, K. (1977). Studies on the carbon balance of Daphnia pulex De Geer as related to environmental conditions. II. The dependence of carbon assimilation on animal size, temperature, food concentration and diet species. Arch. Hydrobiol. Suppl. 48(3/4): 310-335

Langdon, C. J., Waldock, M. J. (1981). The effect of algal and artificial diets on the growth and fatty acid composition of Crassostrea gigas spat. J. mar. biol. Ass. U.K. 61. 431-448

Lee, J. J., Tietjen, J. H., Garrison, J. R. (1976). Seasonal switching in the nutritional requirements of Nitocra typica, a harpacticoid copepod from salt marsh Aufwuchs communities. Trans. Am. Microsc. Soc. 95(4): 628-637

Lehninger, A. L. (1975). Biochemistry. Worth Publishers, New York

Li, W. K. W., Subba Rao, D. V., Harrison, W. G., Smith, J. C., Culler, J. J., Irwin, B., Platt, T. (1983). Autotrophic picoplankton in the tropic ocean. Science 219: 292-295

Loosanoff, V. L. (1954). New advances in the study of bivalve larvae. Am. Scient. 42: 607-624

Loosanoff, V. L., Davis, H. C. (1963). Rearing of bivalve mollusks. Adv mar. Biol. 1: 1-136

Loosanoff, V. L., Miller, W. S., Smith, P. B. (1951). Growth and settling of larvae of Venus mercenaria in relation to temperature. J. mar. Res 10:59-81

Manahan, D. T (1989). Amino acid fluxes to and from seawater in axenic veliger larvae of a bivalve (Crassostrea gigas). Mar. Ecol. Prog. Ser. 53: 247-255

Manahan, D. T (1990). Adaptations by invertebrate larvae for nutrient acquisition from seawater. Am. Zool. 30: $147-160$

McMahon, J. W., Rigler, F. H. (1965). Feeding rate of Daphnia magma Strauss in different foods labeled with radioactive phosphorus. Limnol. Oceanogr. 10: 105-113

Melaouah, N. (1989). Rôle du glucose dissous dans la nutrition des larves de Mytilus edulis. Aquat. Living Resour 2: $145-152$

Millar, R. H., Scott, J. M. (1967). Bacteria-free culture of oyster larvae. Nature 216: 1139-1140

Mitchell, J. G., Fuhrman, J. A. (1989). Centimeter scale vertical heterogeneity in bacteria and chlorophyll a. Mar. Ecol. Prog. Ser. 54(1-2): 141-148 
Nissen, H., Nissen, P., Azam, F. (1984). Multiphasic uptake of D-glucose by an oligotrophic marine bacterium. Mar. Ecol. Prog. Ser. 16: 155-160

Omori, M., Ikeda, T. (1984). Methods in marine zooplankton ecology. Wiley-Interscience, New York

Parsons, T., Takahashi, M. (1973). Biological oceanographic processes. Pergamon Press, New York

Perry, G. J., Volkman, J. M., Johns, R. B., Bavor, H. J. Jr (1979). Fatty acids of bacterial origin in contemporary marine sediments. Geochim. Cosmochim. Acta. 43: $1715-1725$

Provasoli, L., Shiraishi, K., Lance, J. R. (1959). Nutritional idiosyncrasies of Artemia and Tigriopus in monoxenic culture. Ann. N.Y. Acad. Sci. 77: 250-261

Pütter, A. (1909). Die Ernährung der Wassertiere und der Stoffhaushalt der Gewässer. Fischer, Jena

Rivkin, R. V., Bosch, I., Pearse, J. S., Lessard, E. J. (1986). Bacterivory: a novel feeding mode for asteroid larvae. Science 233: $1311-1314$

Sherr, B. F., Sherr, E. B. (1984). Role of heterotrophic protozoa in carbon and energy flow in aquatic ecosystems. In: Klug, M. J., Reddy, C. A. (eds.) Current perspectives in microbial ecology. Am. Soc. Microbiol, Washington, DC, p. 412-423

Sherr, E. B., Sherr, B. F. (1987). High rates of consumption of bacteria by pelagic ciliates. Nature $325: 710-711$

Sokal, R. R., Rohlf, F. J. (1981). Biometry. W. H. Freeman \& Co., San Francisco

Strathmann, R. R. (1967). Estimating the organic carbon content of phytoplankton from cell volume or plasma volume. Limnol. Oceanogr. 12: 411-418

Strathmann, R. R. (1971). The feeding behavior of planktotrophic echinoderm larvae: mechanisms, regulation, and rates of suspension-feeding. J. exp. mar. Biol. Ecol. 6: 109-160

This article was presented by D. K. Stoecker, Cambridge, Maryland, USA
Trider, D. J., Castell, J. D. (1980). Effect of dietary lipids on growth, tissue composition and metabolism of the oyster (Crassostrea virginica). J. Nutr. 110(7): 1303-1309

Ukeles, R. (1969). Nutritional requirements in shellfish culture. In: Price, K. S., Mauder, D. L. (eds.) Proceedings of the conference on artificial propagation of commercially valuable shellfish. Univ of Delaware Press, Newark, p. $43-64$

Walne, P. R. (1956). Experimental rearing of the larvae of Ostrea edulis (L.) in the laboratory. Fishery Invest., Lond. 20(9): $1-22$

Walne, P. R. (1965). Observations on the influence of food supply and temperature on the feeding and growth of the larvae of Mytilus edulis L. Fishery Invest., Lond. 24(1): $1-45$

Webb, K. L., Chu, F. L. E. (1981). Phytoplankton as a food source for bivalve larvae. In: Pruder, G. D., Langdon, C. J., Concklin, D. E. (eds.) Proceedings of the second international conference on aquaculture nutrition: biochemical and physiological approaches to shellfish nutrition. Louisiana State University Press, Baton Rouge, p. $272-291$

Williams, P. N. (1985). Chemistry of the dissolved and particulate phases in the water column. In: Eppley, R. W. (ed.) Plankton dynamics of the Southern California Bight. Springer, New York, p. 53-83

Zhukova, A. I. (1963). On the quantitative significance of microorganisms in nutrition of aquatic invertebrates. In: Oppenheimer, R. W. C. H. (ed.) Symposium on Marine Microbiology. Charles C. Thomas Publisher, Springfield, p. $699-710$

Zobell, C. E., Feltham, C. B. (1938). Bacteria as food for certain marine invertebrates. J. mar. Res. 1: 312-327

Manuscript first received: June 3, 1993

Revised version accepted: August 6, 1993 